\title{
Hematite-coated microfossils: primary ecological fingerprint or taphonomic oddity of the Paleoproterozoic?
}

\author{
R. S. SHAPIRO ${ }^{1}$ AND K. O. KONHAUSER ${ }^{2}$ \\ ${ }^{1}$ Geological and Environmental Sciences Department, CSU Chico, Chico, CA, USA \\ ${ }^{2}$ Department of Earth and Atmospheric Sciences, University of Alberta, Edmonton, AB, UK
}

\begin{abstract}
Microfossils belonging to the 1.88-billion-year-old 'Gunflint-biota' are preserved as carbonaceous and hematitic filaments and spheres that are believed to represent ancient chemolithoautotrophic Fe(II) oxidizing bacteria that grew above a chemocline where ferruginous seawater upwelled into shallow, oxygenated waters. This 'biological' model posits that hematite formed during burial from dewatering of the precursor ferric oxyhydroxides that encrusted Fe(II)-oxidizing bacteria. Here, we present an alternate 'taphonomic' model in which iron-rich groundwaters discharged into buried stromatolites; thus, the mineralization reactions are more informative of diagenetic processes than they are for primary marine conditions. We sampled centimeter-scale columnar stromatolites from both the lower and upper stromatolite horizons of the Biwabik and Gunflint formations, across a range of metamorphic gradients including unaltered to prehnitepumpellyite taconite, supergene altered ore, and amphibolite-pyroxene grade contact-metamorphic zones. Fossils are rare to very rare and comprise curved filaments that exist in clusters with similar orientations. The filaments from throughout the Biwabik are similar to well-preserved carbonaceous Gunflintia from Ontario. Spheres of Huroniospora are also found in both formations. Microfossils from the least altered sections are preserved as carbon. Prehnite-pumpellyite samples are composed of either carbon or hematite $\left(\mathrm{Fe}_{2} \mathrm{O}_{3}\right)$. Within the contact aureole, filaments are densely coated by magnetite $\left(\mathrm{Fe}_{3} \mathrm{O}_{4}\right)$; the highest grade samples are secondarily oxidized to martite. The consistency in stromatolite microstructure and lithofacies throughout the metamorphic grades suggests they formed under similar environmental conditions. Post-depositional alteration led to replacement of the carbon by iron oxide. The facies association, filament distribution, and lack of branching and attached spherical cells argue against Gunflintia being a direct analogue to common marine, chemolithoautotrophic Fe(II)-oxidizing bacteria. Instead, we propose that the presence of hematite-coated microfossils is a reflection of taphonomic processes and does not necessarily reflect the byproduct of an original microbial ecosystem.
\end{abstract}

Received 26 July 2014; accepted 5 January 2015

Corresponding author: R. S. Shapiro. Tel.: 530898 4300; fax: 530898 5234; e-mail: rsshapiro@csuchico. edu

\section{INTRODUCTION}

Since the 1960s, it has been recognized that the microfossils of the Gunflint formation are preserved as both carbonaceous and iron oxide filaments and spheres within a microcrystalline quartz (chert) matrix (Barghoorn \& Tyler, 1965; Awramik and Semikhatov, 1979; Tazaki, 1993; Kudryavtsev et al., 2001; Igisu et al., 2009). However, the taphonomic implications of multiple preservational states have not been fully explained, even as more locations con- taining similar Gunflint microflora were discovered (e.g., Cloud \& Licari, 1968; Knoll \& Barghoorn, 1976; Walter et al., 1976; Cloud and Morrison, 1980; Knoll \& Simonson, 1981; Yun, 1984; Lager, 2001; Yongding et al., 2004). The early focus has been on identification of the microfossils, and less on the processes of preservation (however, see recent papers by Wilson et al., 2010; Edwards et al., 2012).

Taxonomic placement of the microflora has followed exciting trends in microbiology. The original discoveries 
by Moore (1918) and Gruner (1922) referred to the stromatolite fossils as 'algae'. The seminal papers by Barghoorn \& Tyler (1965) and Cloud (1965) placed the microflora in the phylum Cyanobacteria. The criteria used were the relatively large size of the filaments as well as the association with stromatolites. Further work in the 1970s continued to emphasize cyanobacterial affinity (e.g., Awramik \& Barghoorn, 1977). Interestingly, the possibility that the forms could be 'iron-loving' bacteria was voiced as early as 1965 by Barghoorn and Tyler. Indeed, nearly 100 years ago, Harder (1919) postulated the role of $\mathrm{Fe}$ (II)-oxidizing bacteria in forming major iron deposits. The taxonomic implications are critical as the preservation of $\mathrm{Fe}$ (II)-oxidizing bacteria would help solve major questions relating to iron-formation genesis and provides a provocative story in a critical chapter of Earth history - the oxygenation of the atmosphere (Knoll, 2003; Bekker et al., 2010; Posth et al., 2013).

The implication of these various studies is that the hematite coatings preserved in some Paleoproterozoic cherts formed directly from a primary ferric oxyhydroxide precipitate (e.g., ferrihydrite, $\mathrm{Fe}(\mathrm{OH})_{3}$ ) as a response of the metabolism of $\mathrm{Fe}(\mathrm{II})$-oxidizing bacteria. An alternative hypothesis proposed here is that the hematite coatings formed post-depositional due to the input of reduced ironrich fluids in the subsurface. In this regard, the presence of hematite cannot be used as a direct proxy for establishing a primary $\mathrm{Fe}(\mathrm{II})$-oxidizing metabolism and, by extension, allows for an interpretation of seawater composition at the time of stromatolite formation.

\section{Geologic setting}

This study focuses on preserved microfossils from the $1.88 \mathrm{Ga}$ stromatolite intervals of the Biwabik and Gunflint iron formations of the Lake Superior region (Fig. 1). The Biwabik and Gunflint are correlative but separated by the 1.1 Ga Duluth Complex gabbroic intrusions. The iron formations vary in thickness, ranging up to $240 \mathrm{~m}$ thick (Severson et al., 2009). Microfossil-bearing stromatolites are confined within two separate meter-scale intervals of broadly similar facies but containing a diverse assemblage of stromatolite forms (Hofmann, 1969). The upper interval can be traced throughout the Gunflint. In the Biwabik, the upper interval extends from the contact with the gabbroic intrusion west to Hibbing, Minnesota (Severson et al., 2009). The lower interval represents a basal flooding surface atop a detrital interval that ranges from sandstone to conglomerate. In places, stromatolites are observed growing directly upon the eroded Archean substrate. This interval is not continuous but can be found throughout the Biwabik and Gunflint. Stromatolitic boundstone ranges from 10 to $110 \mathrm{~cm}$ thick, and individual biostromes can be continuously traced for $10 \mathrm{~s}$ of meters along walls of open- pit mines. In addition to boundstone, the stromatolite facies include flat-pebble conglomerate and cross-bedded oolite. There is no evidence of intertidal facies, such as herringbone cross-bedding, flaser-bedding, mud cracks, or birds-eye structures. However, rounded intraclasts with desiccation cracks are locally found dispersed with ooids between stromatolite columns (see Markun \& Randazzo, 1980; Fralick, 1988; Pufahl \& Fralick, 2004; and Planavsky et al., 2009 for additional details on the stratigraphy).

The Biwabik-Gunflint iron formations were deposited in peritidal to deep shelf settings in a subsiding back-arc basin (Hemming et al., 1995a,b; Schulz \& Cannon, 2007). A volcanic arc lay to the south, separating the basin from the open ocean. Tholeiitic lava intruded the sequence in the southernmost exposures in Wisconsin and in the Gunflint formation. Following deposition of the iron formations, and postdating the Sudbury impact at $1.85 \mathrm{Ga}$, a major collision to the south led to the main phase of the Penokean orogeny with substantial faulting, metamorphism, and syn-orogenic plutonism toward the south and east. The collision led to the development of a foreland basin causing further subsidence of the Biwabik-Gunflint area. This region then became the depocenter for a thick sequence of shale and turbidites (Virginia and Rove Formations) (Hoffman, 1987; see review in Ojakangas et al., 2011). The next major deformational event was significant rifting and intrusion of gabbro at 1.1 Ga (Miller \& Severson, 2002). Subvolcanic sills of diabase and surface flows of basalt are associated with this large igneous province though there is no evidence of oceanic incursion (Hollings et al., 2010).

Finally, there are regions of enriched ore-leached silica and enriched oxidized iron-associated with fault zones in the Mesabi Iron Range. These mines are known as 'directshipping ore' for their high iron content in contrast to the low iron taconite being mined today. The age of this supergene alteration is unknown but likely related to near surface weathering by heated vadose fluids in the Cretaceous (Simonson, 2011). For details on models of enriched iron ore formation, see Evans et al. (2013).

Both iron concentration and metamorphic grade increases toward the southwest so that the best preserved material is from the northernmost exposures of the Gunflint. In fact, the quality of preservation is so detailed that the region near Thunder Bay, Ontario, and particularly at Schreiber, has been deemed a Paleoproterozoic 'lagerstätten’ (Nudds \& Selden, 2008). Cloud \& Licari (1968) purposefully investigated the Biwabik iron formation to expand the known areal distribution of the Gunflint microflora. They figured a mat of randomly oriented filaments (Gunflintia), a few spheres (Huronisporia), and the possible presence of Eoastrion, from a stromatolite collected from tailings of the direct-shipping ore Corsica Mine, near Gilbert, Minnesota. They also noted that the stromatolite beds of the Upper Cherty Member (= upper 

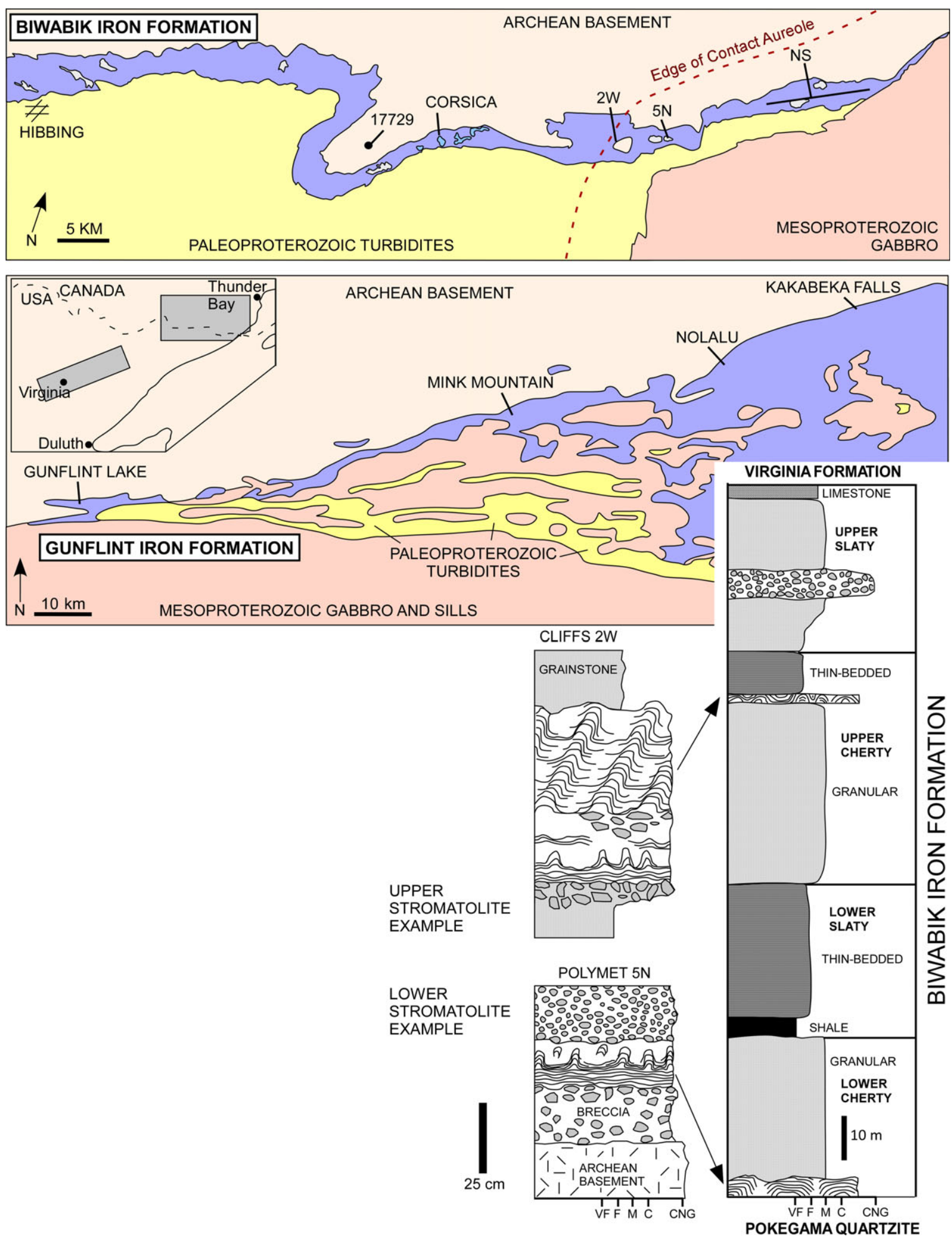

Fig. 1 Simplified geologic map and stratigraphic column. The upper two panels show the outcrop distribution of the Biwabik (upper) and Gunflint (Lower) iron formations relative to the underlying Archean basement and overlying Paleoproterozoic turbidites. Note the intrusive contact of the Mesoproterozoic gabbro and sills. Inset stratigraphic column shows the typical iron-formation lithofacies with details of the two stromatolite beds. Compiled from several columns at the Cliff-Erie mines near Hoyt Lakes, Minnesota. The Gunflint is broadly similar though facies variations substitute throughout. See Table 1 for locations. 
Table 1 Sample locations from the Gunflint and Biwabik iron formations cited in this study

\begin{tabular}{|c|c|c|c|c|}
\hline Location & Latitude (N) & Longitude (W) & Collection & Metamorphic grade \\
\hline Schreiber & 48.80 & 87.34 & Natural & Unmetamorphosed \\
\hline Kakebeka Falls & 48.41 & 89.63 & Natural & Unmetamorphosed \\
\hline Whitefish Falls & 48.29 & 89.84 & Natural & Unmetamorphosed \\
\hline Mink Mountain & 48.24 & 90.16 & Mine & Contact (subgreenschist) \\
\hline Gunflint Lake & 48.09 & 90.82 & Natural & Contact (subgreenschist) \\
\hline Core 17729 & 47.53 & 92.72 & Core & Prehnite-pumpellyite \\
\hline Corsica Pit & 47.51 & 92.12 & Mine Talus & High temperature leached \\
\hline Cliffs-Erie 2W & 47.57 & 92.14 & Mine & Subgreenschist \\
\hline Polymet $5 \mathrm{~N}$ & 47.63 & 92.05 & Mine & Greenschist \\
\hline Northshore & 47.66 & 91.93 & Mine & Amphibolite-Pyroxene \\
\hline
\end{tabular}

interval in this paper) are 'strikingly similar to and probably the equivalent of the stromatolitic zone that has yielded the Gunflint microbiota in Ontario' (p. 781). Most critical to the present paper, they state that the former carbonaceous cell walls have been replaced by hematite. All of the fossils are confined to the stromatolites and are most abundant along 'particular unequally spaced, upwardly convex laminae of the individual stromatolite fingers or ridges'.

\section{MATERIAL AND METHODS}

Stromatolite samples from both the lower and upper stromatolite intervals of the Biwabik and Gunflint iron formations were used in this study (Table 1). Because of the diversity in stromatolite forms, only centimeter-scale columnar to rarely branching columns assigned to Gruneria biwabika (Cloud \& Semikhatov, 1969) was used in this study for consistency. Targets were chosen that represented relatively unaltered, slightly altered (prehnite-pumpellyite), low-grade altered (subgreenschist), and high-temperature leached iron-formations (direct-shipping ore). Samples were also collected from metamorphic gradients (up to amphibolite-pyroxene) within the contact aureole associated with the $1.1 \mathrm{Ga}$ gabbroic large igneous province and associated diabase sills (contact metamorphism). Samples were carefully collected from drill core, natural exposures, and open-pit taconite mines. All samples were located aerially and stratigraphically. Field locations were recorded with an SX Blue II submeter global positioning system (Geneq, Montréal, QC, Canada). Core locations were provided by the state of Minnesota repository in Hibbing. Cores were also provided by U.S. Steel Corporation. In total, 75 thin sections were studied. For comparison between samples, only stromatolite laminae were investigated. Others have reported microfossils from interstitial cements and reworked intraclasts (e.g., Knoll \& Simonson, 1981; Strother \& Tobin, 1987; Edwards et al., 2012).

Thick $(40 \mu \mathrm{m})$ and thin $(30 \mu \mathrm{m})$ sections of rock chips were investigated with standard petrographic and reflected light microscopy techniques. Microfossil and mineral sizes were measured using PaxIT! and Olympus Stream software. Transmitted petrographic images were photographed through an Olympus BX-51 with a $100 \times$ oil immersion objective. Reflected light images were taken through a Nikon Optiphot-POL. Fossil-bearing zones are rare to very rare in the samples that produced fossils. Most thin sections contained no recognizable fossils.

\section{Establishing biogenicity of the filaments}

Recognizing biological filaments are a challenge in the more altered samples. For consistency, only stromatolitic margins were investigated. Areas of localized alteration, in particular fractures, were not studied. To be considered biogenic, filaments had to have curves, exist in clusters with similar forms of random orientations, and not align with crystallographic boundaries. This latter criterion is important as much of the chert is secondary and insoluble residue can be migrated along the growth front of the crystal leading to pseudofossils. An additional criterion, that the filaments occur in facies where they would likely be anticipated, is met by limiting collection to stromatolitic laminae. These criteria are not meant to be universally applied to any potential microfossil in the rock record (e.g., Buick, 1990; Cady et al., 2003), but are thought to provide a sufficient screen for the Gunflint-Biwabik system. Filaments were measured for width and length. Where applicable, the sizes of hematite or magnetite crystals were also measured. It is believed that the filaments described herein can be assigned to Gunflintia Barghoorn (Barghoorn \& Tyler, 1965), common in the Gunflint formation stromatolites.

In the Gunflint formation, spheres assigned to Huroniospora Barghoorn (Barghoorn \& Tyler, 1965) may be quite common. This presumed planktonic form is exceedingly simple in its morphology but is often found in clusters. In this study, putative Huroniospora were noted whether there was a consistency of size, cluster of at least several individuals, and clearly circular outline. All examples were hollow in the center and permineralized by silica. The observations and data are presented here because the morphologies are 
similar to those of better preserved Gunflintia and Huroniospora and may shed light on the taphonomic processes.

\section{RESULTS}

Microfossils were collected from centrimetric columns within domal stromatolites in the basal layer of the Gunflint, as well as centimetric columns and pseudocolumns (assigned to the Form Gruneria biwabika; Cloud \& Semikhatov, 1969) from both the basal and upper layers of both formations (Fig. 2). Domal stromatolites are approximately $1 \mathrm{~m}$ across with irregular, pustulate laminae comprising columns. They are embedded within white to black chert with secondary euhedral ankerite $\left(\mathrm{CaFe}\left(\mathrm{CO}_{3}\right)_{2}\right)$ crystals. Gruneria biwabika columns average $1.8 \mathrm{~cm}$ across and $5 \mathrm{~cm}$ tall. Laminae are generally smooth with a high degree of inheritance. Many columns display a wall margin and linked laminae. Cross-laminae are rare but do occur. All stromatolites are preserved with very fine-grained superficial ooids between columns. Microstructure of the stromatolites becomes increasingly altered toward the gabbroic intrusion (Shapiro, 2009). Microfossils occur in discontinuous intervals along darker laminae.

The best preserved microfossils are found in black chert in the Gunflint; lesser quality fossils are found within ironrich laminae in the Biwabik. Even in the best preserved stromatolites of the Gunflint formation near Kakebeka Falls and Schreiber, Ontario, microfossils are rare, while in the Biwabik, they are very rare though they have been recovered from all metamorphic and diagenetic facies (Fig. 3). There was no definable pattern in location of preservation relative to stromatolite margin, axis or diagenetic front, and even within a defined region of preservation, the quality (sharpness, continuity of outline) is variable.
Fig. 2 Representative stromatolites. (A) Field photo of domal stromatolites composed of $0.5-1 \mathrm{~cm}$ wide columns growing upon conglomerate at base of the Gunflint formation at Schreiber, Ontario. (B) Polished section of tilted columns from prehnitepumpellyite facies of the Biwabik iron formation at Corsica Mine, Minnesota. Upper stromatolite layer. (C) Polished section of hematite-rich hornfels with columns and ooids in the Gunflint formation at Mink Mountain, Ontario. Upper stromatolite layer. Scale bars: $\mathrm{B}=2 \mathrm{~mm} ; \mathrm{C}=0.5 \mathrm{~mm}$.
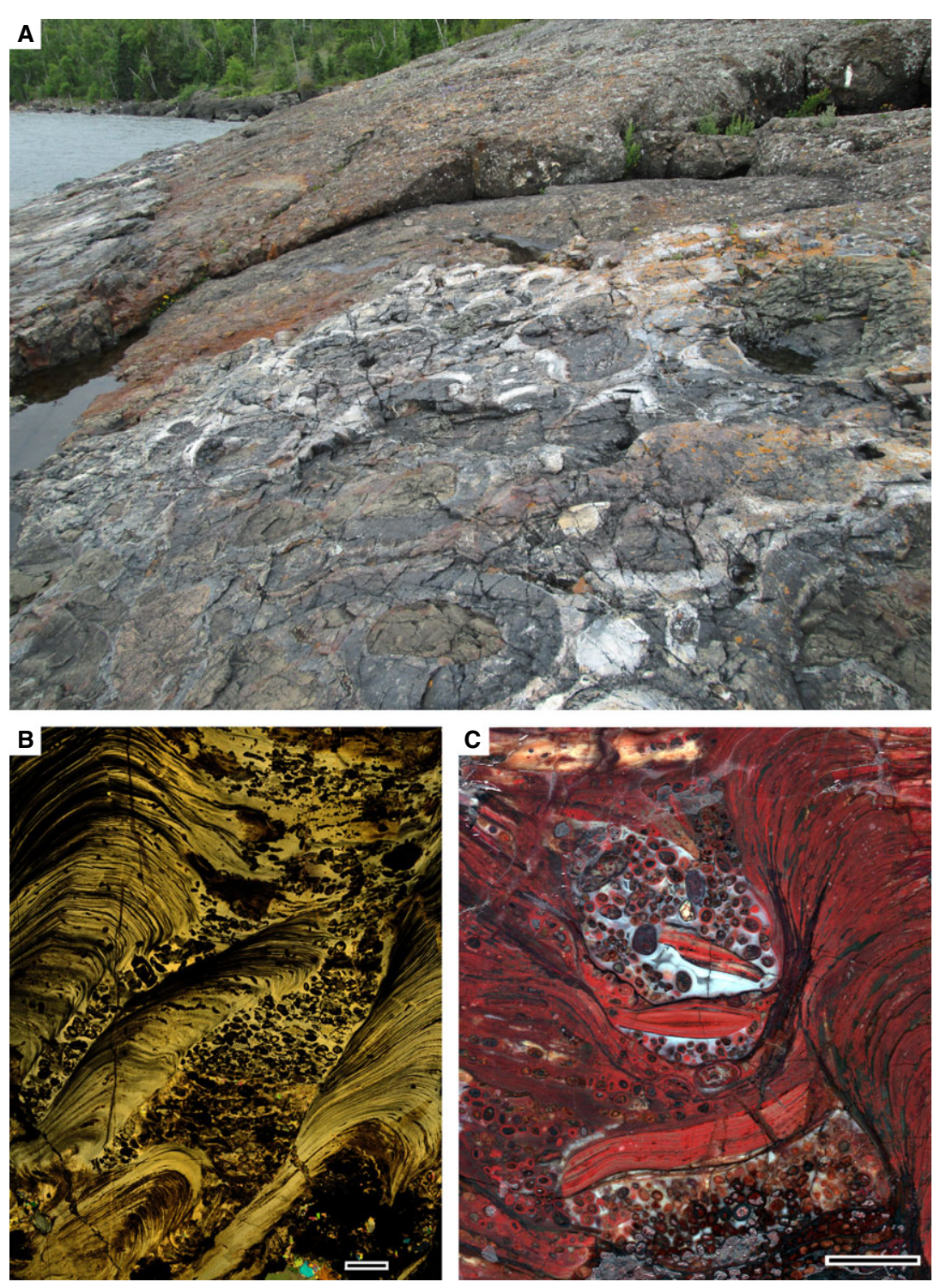


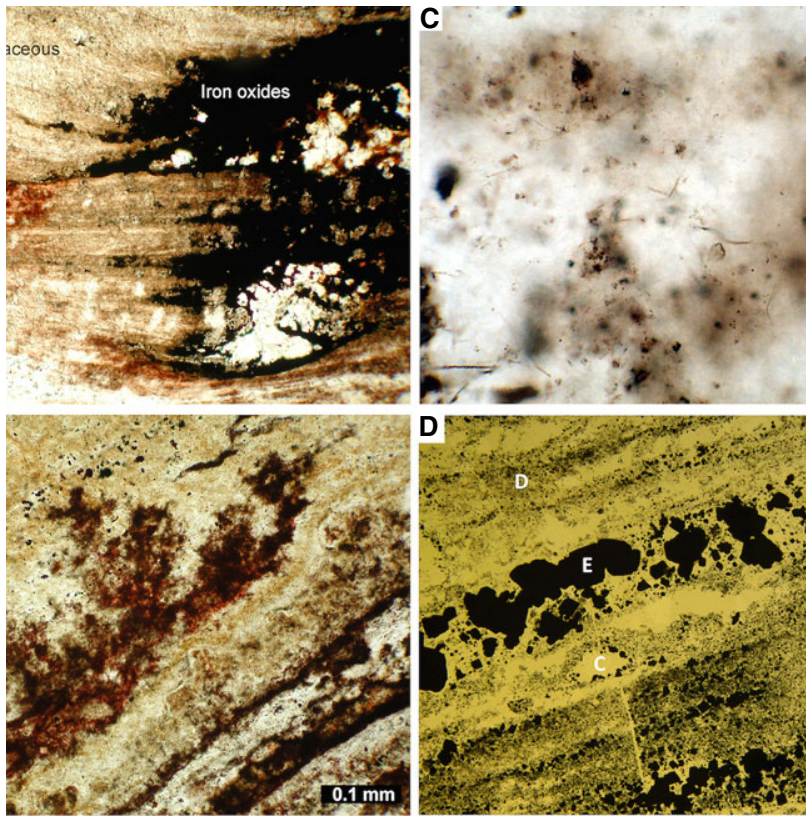

Fig. 3 Examples of stromatolite laminae showing different stages of preservation in relationship to iron oxides. (A) Carbonaceous laminae on left being replaced and destroyed by iron oxides, low-grade contact metamorphic. Mink Mountain, Ontario. (B) Detail of hematite-rich laminae, lowgrade contact metamorphic. Mink Mountain, Ontario. (C) Detail of fossiliferous laminae. Microfossils preserved as hematite, subgreenchist metamorphism. Corsica Mine. (D) Detail of stromatolite laminae showing multiple forms of iron oxide replacement. The laminae are composed of chert with disseminated sub-micron crystals [D] of iron oxides. Larger euhedral crystals [E] are found along the laminae at the center and bottom, as well as lining voids associated with fabric-destructive calcite [C]. Crystals grossly preserve the original lamination. High-grade contact metamorphism (amphibolite). Northshore Mine.

Carbonaceous zones can be common and are often fossiliferous in the Gunflint. In the Biwabik, carbonaceous zones are very rare though anthraxolite is noted in nonstromatolitic facies associated primarily with calcite veins. In most cases, dark laminae that appear promising at lower magnification are dominated by non-fossiliferous iron oxide (hematite or magnetite) aggregates. In general, more carbonaceous zones are found toward the margins of the stromatolite columns.

Submillimeter-scale iron oxides are common components of the background chert throughout the Biwabik and more rarely in the Gunflint. Near Thunder Bay and Schreiber, Ontario, iron oxides are concentrated in small pockets several millimeters across that do not have a preferred orientation or stratigraphic position relative to the stromatolite fabric. Additional iron oxides are present as sub-micron euhedral to subhedral crystals that preferentially concentrate along stromatolite laminae. Opaque iron oxides are also observed along margins of superficial ooids and disseminated between grains in the intercolumnar fill.
In all locations, the dominant microfossil is assigned to Gunflintia though poor preservation precludes a species diagnosis (Fig. 4A-C). Huroniospora is rare but can locally dominate some laminae and they always occur in association with Gunflintia (Fig. 4D-E). Other genera, such as Eoastrion, are noted in the Gunflint but have not been clearly identified in the Biwabik. What is noteworthy is that there is size variation amongst microfossil type depending on locality yet the span is within the range of error (Fig. 4F; see references in Table 2). For instance, Gunflintia can vary twofold at the same location (i.e., Kakabeka Falls, Northshore Mine), whereas Huroniospora ranges in size depending on actual location. In the case of Huroniospora, unaltered fossils at Kakabeka are larger than the ironencrusted cells at Northshore Mine or Corsica Mine. This is surprising because with primary iron-staining one would predict the opposite trend that being that the cell-mineral aggregate should exceed the size of the unmineralized cell. One plausible explanation is that the Northshore and Corsica cells had already degraded, and thus were smaller in size, prior to iron mineralization (see Oehler, 1976 for experimental studies on bacterial silicification). Another explanation is that the simple morphology represents two or more species of spherical structures.

Preservation of the microfossils occurs as both carbonaceous and iron oxide-coated structures (e.g., Bower et al., 2010). In all cases, the filaments (Gunflintia) or spheres (Huroniospora) are embedded within chert. The preservational state is, in part, related to metamorphic conditions. Carbonaceous filaments are only found in the lowest grade (sub-prehnite-pumpellyite) outcrops in the northern exposures of the Gunflint near Thunder Bay (e.g., Kakebeka Falls; Schreiber) (Fig. 4A,D). In those locations, cellular outline is well preserved, with for example, some of the Gunflintia filaments appearing to have their septae visible (Fig. 4A), while in Huroniospora, the cell wall clearly stands out in contrast to the chert background (Fig. 4B). Where the Gunflint is close to contacts with the diabase sills, the microfossils are carbon-poor and replaced by hematite (Fig. 4E), as evident with reflected light microscopy. In these locations, such as Mink Mountain, Ontario, there is abundant dispersed fine hematite throughout the stromatolite lithofacies, including the ooids and intercolumnar spaces. In the Biwabik, deep cores outside of the contact aureole contain microfossils preserved in hematite (e.g., core 17729). Indeed, stromatolites from the enriched, 'direct-shipping ore' mines contain exclusively microfossils preserved in fine-grained hematite. Closer to the contact with the main gabbro body, there is an increase in the hematite crystal size (Fig. 5). In addition to coating microfossils, there is also an increase in dispersed submicron-scale hematite throughout the microquartz. At the highest grades (amphibolite), the hematite coating is remineralized (and partly reduced) to magnetite, with the 
Fig. 4 Comparison of microfossils from different locations. All images are at the same scale (bar is $25 \mu \mathrm{m}$ ) and images are in plane polarized light. A-C are of Gunflintia and D-E are Huroniospora. (A) The least altered carbonaceous filaments from Kakabeka Falls, Ontario. (B) Well-preserved hematite coated sheath from core 17729. (C) Martitemagnetite preserved filament from the amphibolite-grade Northshore Mine directly adjacent to the gabbro intrusion. (D) Unaltered carbonaceous Huroniospora from Kakabeka Falls. (E) Low-grade alteration of the filaments to coarse hematite, Corsica Natural Ore mine. (F) Graph comparing sizes of microfossils. $N=141$. All values given in micrometers. See Fig. 1 and Table 1 for locations.
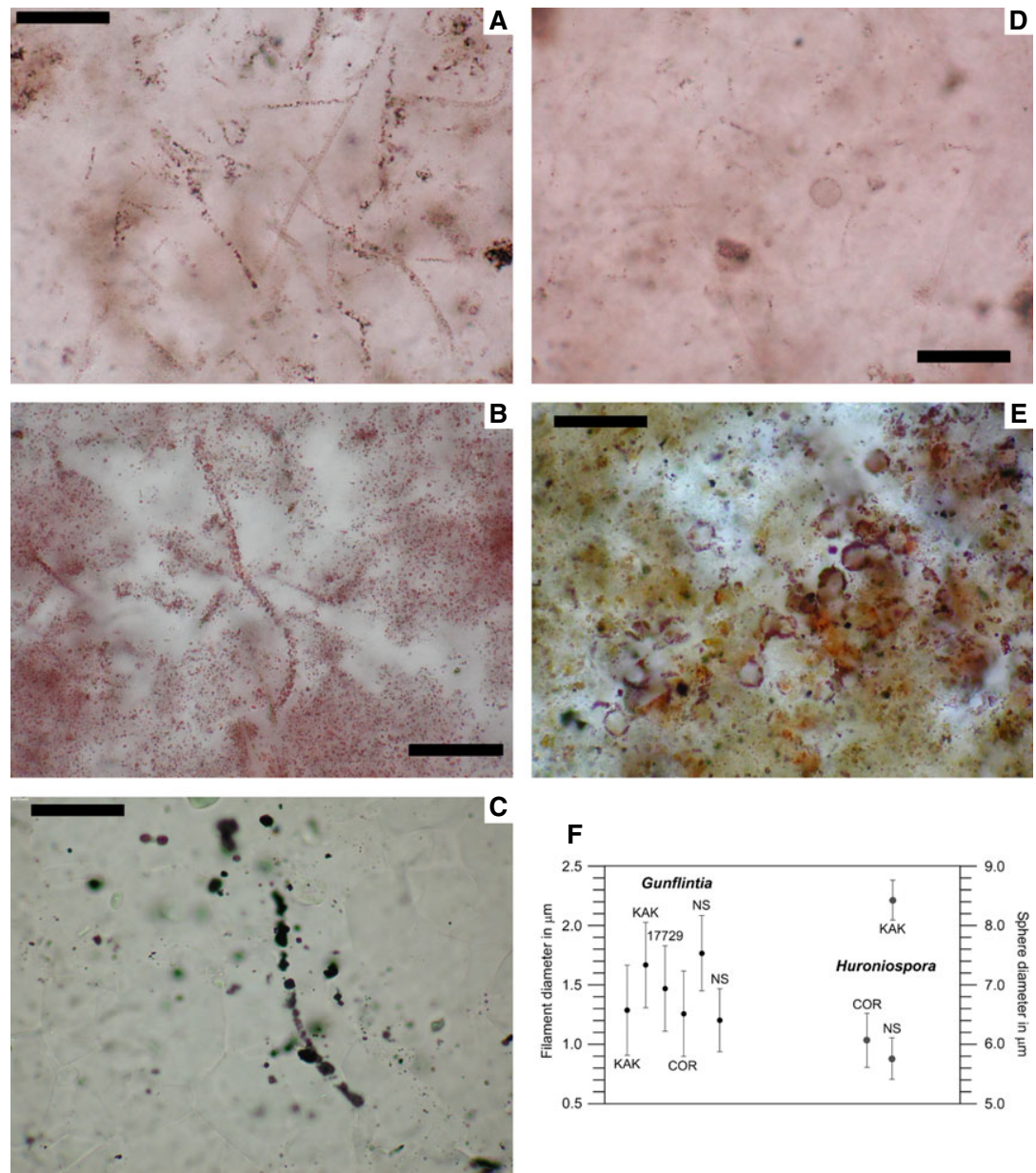

Table 2 Locations of Paleoproterozoic Gunflintia-biota and preservation

\begin{tabular}{|c|c|c|c|c|}
\hline Formation & Age (Ga) & Location & Preservation & Reference \\
\hline Xuanlong & $\sim 1.8$ & Hebei, China & Carbon + Hematite & Juying (1996) \\
\hline Frere & 1.85 & Western Australia & Carbon + Hematite & $\begin{array}{l}\text { Walter et al. (1976) and } \\
\text { Tobin (1990) }\end{array}$ \\
\hline Duck Creek & 1.85 & Western Australia & Carbonaceous & Knoll \& Barghoorn (1976) \\
\hline Ferriman & 1.88 & Quebec, Canada & Silica & Edwards et al. (2012) \\
\hline Sokoman & 1.88 & NE Canada & Carbonaceous & Knoll \& Simonson (1981) \\
\hline Gunfint & 1.88 & Ontario, Canada & Carbon + Hematite & Barghoorn \& Tyler (1965) \\
\hline Biwabik & 1.88 & Minnesota, USA & Hematite & Cloud \& Licari (1968) \\
\hline Tyler & 1.87 & Michigan, USA & Hematite & Cloud \& Morrison (1980) \\
\hline Dannemora & $\sim 1.9$ & Sweden & Hematite & Lager (2001) \\
\hline Franceville & 2.0 & Gabon & Carbonaceous & Amard \& Bertrand-Sarfati (1997) \\
\hline
\end{tabular}

latter showing an increase in size closer to the contact (Fig. 4C). In rare cases, the magnetite is secondarily oxidized back to a variety of hematite known as martite. In these cases, it retains the octahedral crystal shape of magnetite.

While there is a consistency of facies within the shallow-water deposits, the concentration and distribution of iron varies widely on all scales from hand samples to cores and within a mine to locations between mines.
The most obvious example is the essentially iron-poor microfossil-bearing stromatolite beds of the northern Gunflint formation. Yet, even in the classic locality at Schreiber and outcrops at Whitefish Falls near Nolalu, there are centimeter-scale zones of iron oxides within the iron-poor stromatolites (Fig. 6). Other authors noted the patchiness in hematite with regard to microfossils (Barghoorn \& Tyler, 1965). The Cliffs-Erie Mine near Hoyt Lakes also shows dramatic iron variation at the $10 \mathrm{~s}$ 


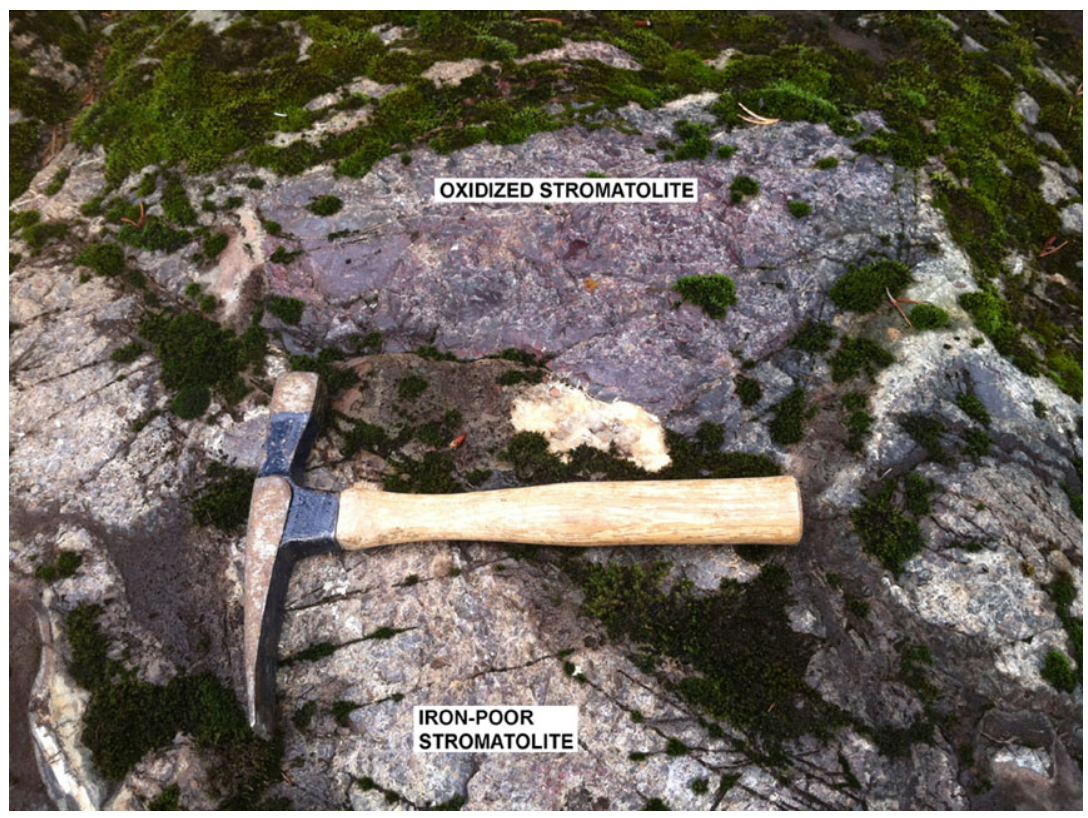

Fig. 5 Field shot showing zone of red, oxidized iron-rich stromatolite surrounded by iron-poor stromatolite preserved as white and black chert. Nolalu, Ontario.

to 100 s of lateral meter scale (mapping by Shapiro, 2002-2010). Severson et al. (2009) present stratigraphic correlations of the Biwabik iron formation that show iron variation as economic zones.

\section{DISCUSSION}

\section{The biologic model}

There are a number of micro-organisms, the so-called iron-depositing bacteria, that facilitate ferric oxyhydroxide

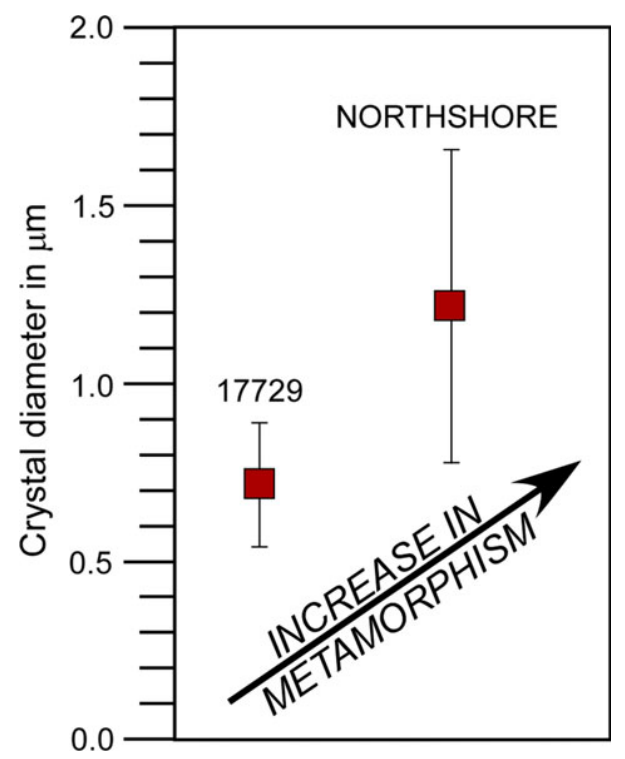

Fig. 6 Graph comparing sizes of iron oxides from low-grade alteration (core 17729) and from within the contact aureole (Northshore). See images in $4 \mathrm{~B}$ and $4 \mathrm{C}$ for examples of preservation. mineralization by having surface ligands that promote $\mathrm{Fe}$ (II) oxidation, although it is not believed that they gain energy from the process (see Emerson, 2000 for review). The most common visible inhabitant of many modern, freshwater, low-oxygenated iron seeps is Leptothrix ochracea. This chemoheterotroph frequently forms thick filamentous layers comprising tangled matrices of tubular sheaths (extracellular organic structures) encrusted in the mineral ferrihydrite. In an iron seep in Denmark, cell counts are approximately $10^{8}-10^{9}$ cells $\mathrm{cm}^{-3}$ (Emerson \& Revsbech, 1994a). Those high bacterial densities promote ferrihydrite accumulation rates of $3 \mathrm{~mm} \mathrm{day}^{-1}$ (Emerson \& Revsbech, 1994b). One interesting observation made was that it was rare to find intact filaments of $L$. ochracea cells inside the sheaths. This correlates well with experiments that have shown Leptothrix continuously abandons its sheath at a rate of $1-2 \mu \mathrm{m} \mathrm{min}^{-1}$, leaving behind sheaths of 1-10 cells in length that continue to deposit ferrihydrite. This would seem to indicate that the microorganisms actively prevent themselves from becoming permanently fixed into the mineral matrix (van Veen et al., 1978) by producing a sheath that acts both as an alternative mineral nucleation site to cell wall and/or cytoplasmic mineralization and by providing a physical filter that restricts mineral formation to its outer surface (e.g., Phoenix et al., 2000). Moreover, Nealson (1982) suggested that L. ochracea, induces ferrihydrite precipitation on its sheath as a means to remove any free oxygen and thus detoxify its environment. Other heterotrophic bacteria, such as filamentous species from the Sphaerotilus, Crenothrix, Clonothrix, and Metallogenium genera, as well as unicellular cocci of the Siderocapsaceae family, can induce ferrihydrite precipitation through oxidation of organic iron 
chelates (i.e., they use the organic carbon of such ligands as an energy source), and in doing so, the iron is freed and easily hydrolyzed (Ghiorse \& Ehrlich, 1992).

The formation of ferrihydrite may also stem from the ability of some chemolithoautotrophic bacteria to oxidize ferrous iron as an energy source. Although most enzymatic oxidation of $\mathrm{Fe}(\mathrm{II})$ occurs at extremely low $\mathrm{pH}$, such as in acid mine drainage environments, the activity of Acidithiobacillus ferrooxidans or Leptospirillum ferrooxidans generally does not promote in situ ferrihydrite precipitation because the $\mathrm{Fe}^{3+}$ formed remains soluble until more alkaline $\mathrm{pH}$ conditions ensue. However, at neutral $\mathrm{pH}$, and under partially reduced conditions, chemolithoautotrophic $\mathrm{Fe}(\mathrm{II})$ oxidation by the genus Gallionella does undeniably lead to high rates of ferric iron mineralization (e.g., Søgaard et al., 2000). Gallionella ferruginea has a beanshaped cell that grows at the terminus of a helical structure called a stalk, which is made up of polysaccharides. Interestingly, G. ferruginea does not form a stalk at $\mathrm{pH}<6$, or under very microaerobic conditions where $\mathrm{O}_{2}$ is present but the redox potential is $-40 \mathrm{mV}$. This suggests that the stalk represents an organic surface upon which ferrihydrite can precipitate and, in doing so, protects the cell itself from becoming mineralized (Hallbeck \& Pederson, 1990; Fleming et al., 2013; Saini \& Chan, 2013). Similar to L. ochracea, Gallionella species are common inhabitants of iron springs, and where they are abundant, the stalk material appears to form the substratum upon which subsequent $\mathrm{Fe}$ (II) oxidation occurs. The recent discovery of an iron-encrusted and stalk-forming bacterium from a freshwater seep in Delaware (FeOB strain R-1) that is physiologically similar to $G$. ferruginea but phylogentically distinct, extends the known diversity of $\mathrm{Fe}(\mathrm{II})$ oxidizing bacteria in freshwater environments (Krepski et al., 2012). Several strains of marine $\mathrm{Fe}(\mathrm{II})$-oxidizing bacteria (e.g., Mariprofundus ferrooxydans) have also been isolated from the Loihi Seamount at Hawaii (Emerson \& Moyer, 2002; Emerson et al., 2007), submarine volcanoes on the South Tonga Arc (Forget et al., 2010), and a salt marsh in Maine (McBeth et al., 2011). Similar to their freshwater counterparts, M. ferrooxydans grows under microaerophilic conditions and produces filamentous stalks composed of ferrihydrite.

Planavsky et al. (2009) recognized that the simple morphology of Gunflintia Barghoorn (Barghoorn \& Tyler, 1965 ) is as comparable to Leptothrix sp. as it is to the cyanobacteria. A similar conclusion was drawn earlier by Knoll \& Simonson (1981) in their study of the coeval fossils from the Sokoman Iron Formation in the Labrador Trough, Canada. Other fossil forms are morphologically similar to modern Gallionella, Mariprofundus, Crenothrix, and other aerobic Fe(II)-oxidizers. Planavsky et al. (2009) acknowledged that morphology alone cannot prove the existence of $\mathrm{Fe}(\mathrm{II})$-oxidizers at $1.9 \mathrm{Ga}$ so they employed
$\mathrm{Ce}$ anomalies, $\mathrm{Eu}$ concentrations, and $\mathrm{Fe}$ isotopes to show that the stromatolites formed at or just below a strong redoxcline in suboxic conditions. Therefore, it was their opinion that chemolithoautotrophic $\mathrm{Fe}(\mathrm{II})$-oxidizers produced the stromatolites and not cyanobacteria. Schelble et al. (2004) similarly discussed the Gunflint formation samples from Mink Mountain as an example of how bacterial filaments became fossilized in ferric oxyhydroxides by drawing attention to processes such as iron adsorption to bacterial cell walls. Wilson et al. (2010) also placed similar microfossils within an $\mathrm{Fe}(\mathrm{II})$-oxidizing ecosystem based on facies analysis in the coeval Duck Creek Formation of Western Australia. Recently, Edwards et al. (2012) revisited the Sokoman and again suggested the presence of $\mathrm{Fe}(\mathrm{II})$-oxidizers based on inferred primary hematite cements and microbial morphology revealed by secondary electron imaging (SEI) scanning electron microscopy. However, the microfossils themselves are not preserved in hematite but are permineralized by silica. The authors attributed this preservation to the microfossil's position above the Fe-redox interface where rapid rates of silicification dominate.

In all of the models above, there is a general assumption that the iron coatings are a primary feature in that the initial $\mathrm{Fe}(\mathrm{II})$ oxidation took place in the water column by benthic bacteria to form ferrihydrite, the ferric iron precursor to more stable iron oxides (e.g., hematite) found in iron formations (Fig. 7A). For instance, it was Holm (1989) who postulated that aerobic chemolithautotrophs (e.g., Gallionella) could have produced the enormous iron formation deposits of the Archean-Paleoproterozoic under microaerobic conditions [reaction 1]:

$$
\begin{aligned}
6 \mathrm{Fe}^{2+} & +0.5 \mathrm{O}_{2}+\mathrm{CO}_{2} \\
& +16 \mathrm{H}_{2} \mathrm{O} \rightarrow\left[\mathrm{CH}_{2} \mathrm{O}\right]+6 \mathrm{Fe}(\mathrm{OH})_{3}+12 \mathrm{H}^{+}
\end{aligned}
$$

Following this possibility, Widdel et al. (1993) built a model where $\mathrm{Fe}^{2+}$ was oxidized by anoxygenic phototrophic purple and green bacteria when coupled with $\mathrm{CO}_{2}$ reduction, thus removing the need for free oxygen during $\mathrm{Fe}(\mathrm{II})$-oxidation [reaction 2]:

$$
\begin{aligned}
4 \mathrm{Fe}^{2+}+\mathrm{CO}_{2}+11 \mathrm{H}_{2} \mathrm{O} & +h v \rightarrow\left[\mathrm{CH}_{2} \mathrm{O}\right] \\
& +4 \mathrm{Fe}(\mathrm{OH})_{3}+8 \mathrm{H}^{+}
\end{aligned}
$$

Konhauser et al. (2002) and Kappler et al. (2005) extended these hypotheses to quantify the $\mathrm{Fe}(\mathrm{II})$ oxidation capabilities of the bacterial populations and showed that these bacteria could be responsible for precipitating the vast volume of iron now incorporated into banded iron formations (BIF) even without cyanobacterial influence. The original ferrihydrite precipitate then became buried and through diagenesis transformed into hematite. Indeed, this view correlates well with models pertaining to the origins of BIF in 

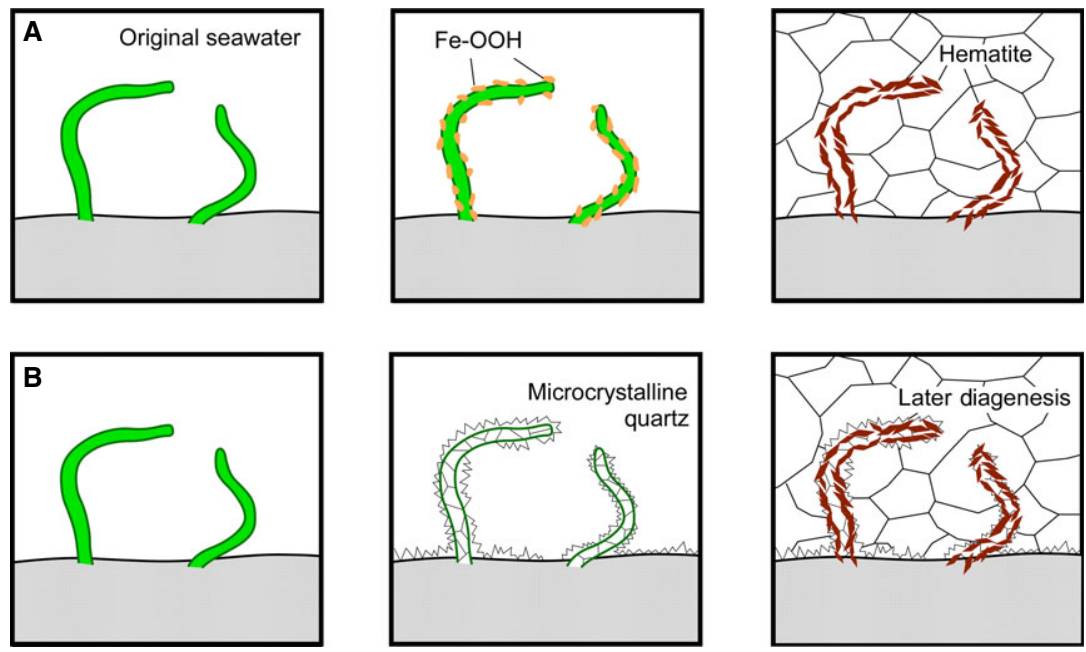

Fig. 7 Models to explain hematite-encrusted microfossils. (A) In the 'Biological Model', iron-oxidizing bacteria promoted the precipitation of iron oxyhydroxides, such as ferrihydrite, onto their sheaths. The ferrihydrite was transformed to hematite on the seabed and preserved in microquartz. (B) In the 'Taphonomic Model', filaments were initially preserved as carbonaceous sheaths. During burial, Fe(II)-rich groundwater infiltrated porous zones of the stromatolite. The cellular remains then either adsorbed $\mathrm{Fe}^{2+}$ or became encrusted via siderite precipitation. At a later stage, the percolation of oxygenated groundwaters oxidized both the $\mathrm{Fe}(\mathrm{II})$ and organic carbon, while porosity was eventually occluded by a second stage of silica cementation. which there were hydrothermal pulses of dissolved $\mathrm{Fe}^{2+}$ into the photic zone of Archean and Paleoproterozoic oceans where it was oxidized to ferrihydrite via biologic activity, and ultimately, incorporated into the sedimentary record (Konhauser et al., 2002; Kappler et al., 2005; Bekker et al., 2010; Li et al., 2011; Posth et al., 2013). Konhauser et al. (2005) further developed a model that used phytoplankton biomass to fuel microbial $\mathrm{Fe}(\mathrm{III})$ reduction, whereby the reduced iron (as $\mathrm{Fe}^{2+}$ ) would subsequently be incorporated in the sediments as magnetite or siderite $\left(\mathrm{FeCO}_{3}\right)$. This model has since been supported by experimental studies which have demonstrated that the iron-containing BIF minerals can be formed by subjecting mixtures of organic carbon (i.e., biomass) and ferrihydrite to pressure and temperature conditions encountered during burial (e.g., Köhler et al., 2013; Li et al., 2013).

One important aspect that the above models do not readily explain is the variable distribution of iron content in the shallower-water granular iron formations (GIF) that may host stromatolites. Nor do they adequately explain why some microfossils are preserved as carbonaceous filaments (Gunflintia) or spheres (Huroniospora), while in other locations those same microfossils are preserved in hematite if one assumes that the iron was sourced from the open oceans via upwelling (Holland, 1973) or hydrothermal plumes (Isley, 1995). Finally, the critical steps of (i) conversion to hematite via dehydration near the sediment surface and (ii) burial preservation of the hematite-enclosed biota in deep time has not been demonstrated for a significant area outside of hydrothermal vents (e.g., Slack et al., 2007; Krepski et al., 2013). In this regard, we provide an alternative explanation which proposes that those fossils were iron mineralized during burial, and that neither Gunflintia or Huroniospora are actually fossilized remains of $\mathrm{Fe}(\mathrm{II})$-oxidizing bacteria.

\section{The taphonomic model}

The general rarity of microfossils points to pervasive, but incomplete, decomposition before fossilization. In the 'taphonomic model' presented here, the critical point is that the microfossils were initially preserved as carbonaceous remains that morphologically outlined the original microbe, and it is during burial conditions that the carbon was oxidized and hematite preserved the morphology. The taxonomic affinity of the organism is not relevant, but what is important is that some of the carbonaceous organic material was preserved through burial and early diagenesis (Fig. 7B). We do not know how this occurred, but several possibilities exist. First, primary silicification of intact microbial biomass could have preserved certain cellular features that are more recalcitrant to decomposition, such as the sheaths or cell walls of filamentous species (e.g., Knoll, 1985). The processes of microbial silicification are well described at modern hot springs today (see Konhauser et al., 2004 for review), and for this to have been a viable mechanism for the Gunflint, it would have necessitated that the seawater in which the stromatolites grew became supersaturated with respect to amorphous silica; Proterozoic seawater itself would not have facilitated silicification unless the waters were evaporated (Orange et al., 2013) or significantly cooled (Yee et al., 2003). Second, in many modern marine stromatolites, cyanobacteria are preserved by calcification (see Dupraz et al., 2009 for review). Although there is no evidence in favor of calcium carbonate preserving the initial micro-organisms, it cannot be ruled out because diagenetic fluids moving through the stromatolite may have been slightly acidic, leading to replacement of the primary carbonates by silica (e.g., Knauth, 1979; Knoll, 1985; Hesse, 1989). This replacement can often by highly selective in that silicification 
occurs preferentially in facies with relatively high concentrations of organic matter (e.g., Fairchild et al., 1991; Altermann \& Schopf, 1995). Third, and irrespective of a primary mineralization mechanism, the organic polymers comprising cell sheaths and walls are more resilient to degradation than other cell components, and as long as the constituent autolysins are deactivated (i.e., by the presence of adsorbed iron to the cell wall), they can persist in the environment long after the cell dies (Ferris et al., 1988). The preservation of some organic remains may also have been enhanced due to the lower levels of dissolved sulfate in the oceans around $1.88 \mathrm{Ga}$ (Poulton et al., 2004); in modern marginal marine settings sulfate serves as the terminal electron acceptor for the oxidation of up to $50 \%$ of buried organic carbon (Jørgensen, 1982). Similar to the modern, the organic matter that was degraded by anaerobic respiration would have led to increased pore-water alkalinity via the production of bicarbonate, and possibly carbonate mineral precipitation. Indeed, both fine-grained siderite, followed by early diagenetic ankerite rhombs, are commonly associated with stromatolites in the Gunflint and Biwabik iron formations (Shapiro, 2009). During later contact metamorphism, coarse calcite formed as a fabricdestructive petrofabric along with hematite.

In the case of the hematite-coated microfossils described herein, we suggest that iron mineralization itself was not associated with the mat-forming species (e.g., Fischer \& Knoll, 2009; Planavsky et al., 2009), but instead when some of those preserved cellular remains reacted with dissolved ferrous iron after stromatolite burial. The source of the $\mathrm{Fe}^{2+}$ was not from the water column (e.g., marine hydrothermal plumes or upwelling events), but iron-rich groundwater moving through the still porous sedimentary rocks. With numerous avenues for fluids to flow, some stromatolites were more susceptible to iron mineralization than others, hence the patchiness in iron concentrations. Interestingly, the same porosity that allowed iron-rich fluids to flow through the stromatolite also eventually caused it to become occluded. Based on textural evidence, it is clear that multiple stages of silicification took place during the stromatolite's history. As mentioned above, some silicification may have played a primary role in preserving some of the initial cellular remains. Some of the silica was likely early diagenetic based on crystal orientation mimicking fringing cement and occluding primary porosity. The majority of silica is clearly late, filling secondary porosity and encasing hematite coatings in chert that replaces primary fabrics.

The actual timing of $\mathrm{Fe}(\mathrm{II})$ oxidation is unclear. On the one hand, as the reduced ferruginous fluids moved upwards into the buried, but still porous, stromatolite, the ferrous iron might have reacted with shallow $\mathrm{O}_{2}$-bearing fluids [reaction 3], and ferrihydrite precipitated upon the cellular remains (scenario 1). Alternatively, $\mathrm{Fe}^{2+}$-rich groundwaters permeated the stromatolite earlier, with cellular remains electrostatically adsorbing $\mathrm{Fe}^{2+}$ (e.g., see Clarke et al., 1997; Konhauser et al., 1998 for examples of natural iron biomineralization of cellular remains) or with $\mathrm{Fe}^{2+}$ precipitating as a ferrous iron mineral phase, such as siderite, greenalite or stilpnomelane (e.g., see Rasmussen et al., 2014 for 2.5 Ga Dales Gorge Formation). Thereafter, shallow oxygenated waters oxidized the cell-bound $\mathrm{Fe}$ (II) to $\mathrm{Fe}(\mathrm{OH})_{3}$ (scenario 2). In either case, the ferrihydrite later transformed into secondary minerals, including (i) magnetite or iron carbonates when organic mineralization was coupled with $\mathrm{Fe}(\mathrm{III})$ reduction [reaction 4-6], or (ii) hematite when the organic material was depleted [reaction 7]. The key point with regard to hematite formation is that the $\mathrm{Fe}(\mathrm{III})$ : C ratio exceed $4: 1$ - the $\mathrm{Fe}(\mathrm{III})$ reduction ratio [reaction 4] - so that ferric iron is retained without an available reductant. The excess $\mathrm{Fe}(\mathrm{III})$ may have resulted from either all initial organic carbon being oxidized or a secondary input of dissolved iron.

$$
\begin{gathered}
4 \mathrm{Fe}^{2+}+\mathrm{O}_{2}+10 \mathrm{H}_{2} \mathrm{O} \rightarrow 4 \mathrm{Fe}(\mathrm{OH})_{3}+8 \mathrm{H}^{+} \\
\mathrm{CH}_{3} \mathrm{COO}^{-}+8 \mathrm{Fe}(\mathrm{OH})_{3} \rightarrow 8 \mathrm{Fe}^{2+}+2 \mathrm{HCO}_{3}^{-}+15 \mathrm{OH}^{-} \\
+5 \mathrm{H}_{2} \mathrm{O} \\
8 \mathrm{Fe}^{2+}+16 \mathrm{Fe}(\mathrm{OH})_{3}+16 \mathrm{OH}^{-} \rightarrow 8 \mathrm{Fe}_{3} \mathrm{O}_{4}+32 \mathrm{H}_{2} \mathrm{O} \\
8 \mathrm{Fe}^{2+}+16 \mathrm{HCO}_{3}^{-} \rightarrow 8 \mathrm{FeCO}_{3}+8 \mathrm{H}_{2} \mathrm{O}+8 \mathrm{CO}_{2} \\
2 \mathrm{Fe}(\mathrm{OH})_{3} \rightarrow \mathrm{Fe}_{2} \mathrm{O}_{3}+3 \mathrm{H}_{2} \mathrm{O}
\end{gathered}
$$

Given the known geological history of the region, it is most likely that the ferruginous groundwater was driven firstly by the tectonic front of the Penokean Orogeny to the south $\sim 40$ million years after deposition of the iron formation (Schulz \& Cannon, 2007), but the exact timing of the oxygenated fluids cannot be clearly delineated. This would account for the much broader distribution of iron in the Biwabik (and southern Superior formations such as the Ironwood in Wisconsin and the Negaunee in Michigan; Ojakangas et al., 2011) relative to the Gunflint. Additional $\mathrm{Fe}(\mathrm{II})$-rich groundwaters would be locally sourced from the intrusive dikes and sills associated with the large igneous complex at 1.1 Ga. Indeed, the Mink Mountain locality contains much higher iron content than other sections of the Gunflint and is more closely associated with a large diabase sill than other locations in the Thunder Bay area. In the Mesabi iron range, there is a well-established increase in metamorphic grade and increase in hematite and magnetite in the stromatolite layers with proximity to the main Duluth Gabbro body (French, 1973; Frost et al., 2007; Hyslop et al., 2008; 
Shapiro, 2009). Late stage oxidation of reduced iron silicates and carbonates was also described by Rasmussen et al. (2014) to account for hematite deposits that postdated deposition and pre-dated modern weathering processes in a Neoarchean iron formation.

\section{Taphonomic support}

The Gunflint microbiota may be constrained to the late Paleoproterozoic but representatives are found in many non-continguous locations and in different facies (Sergeev, 2009 and Table 2). Therefore, any discussion on the taxonomic affinity needs to take into account the varied ecologic settings. For instance, a similar microflora was reported from the coeval Sokoman iron formation (Knoll \& Simonson, 1981). A dense population of Gunflintia filaments comprises the thin laminae of a stromatolite that is similar to a type described from the Gunflint formation. Like the Biwabik, these microfossils are preserved as fine hematite outlines. Twenty percent of the stromatolite microflora is composed of Huroniospora spheres. The authors noted that they were unable to determine whether the fossils were of cyanobacteria or Sphaerotilus/Leptothrix-like iron-depositing bacteria. A rich biota of carbonaceous fossils, including Gunflintia, Huroniospora, as well as Eoastrion and the rare Archueorestis, were also reported from cherty stromatolites in the coeval Franceville Group of Gabon (Amard \& Bertrand-Sarfati, 1997). A survey of other locations shows that Gunflint-type microbiota were similarly recovered from rip-ups and finely laminated chert (Awramik \& Barghoorn, 1977; Wilson et al., 2010). These observations confirm earlier reports that the Gunflint microbiota-including the morphologically simple Gunflintia and Huroniospora, as well as the more complex Eoastrionis widespread and occurs in multiple diverse ecologic settings (e.g., Tobin, 1990).

It is also interesting to note than in a recent study, Salama et al. (2013) presented observational evidence for diagenetic ferruginous stromatolites and oncoids in the Eocene of Egypt. These meter-scale deposits accumulated in lagoonal-peritidal settings associated with syndepositional tectonism. The stromatolites are both stratiform and microcolumnar; oncoids range from 2 to $60 \mathrm{~mm}$ diameter. Laminae consist of alternating goethite and ferrihydrite with goethite-encapsulated sheaths. Some organic components are preserved (carotenoids, carbohydrates, lipids, etc.). The authors postulated that the ferrous iron was sourced from below via a porous aquifer under reducing and acidic conditions (Dabous, 2002). The actual growth medium is believed to have been at approximately neutral $\mathrm{pH}$, low $f\left(\mathrm{O}_{2}\right)$ conditions. It is interesting to note that calcareous skeletal material (algae and benthic foraminifera) were also replaced by iron oxyhydroxides, demonstrating the post-deposition, diagenetic source of iron mineralization.
The most convincing support of the 'Taphonomic Model' is the fact that Gunflintia (and Huroniospora) are found in different modes of preservation (carbonaceous filaments, encapsulated by hematite, and as siliceous molds). Either the simple Gunflintia is a morphotype for both cyanobacteria in some locations and $\mathrm{Fe}(\mathrm{II})$-oxidizing bacteria in other locations (Planavsky et al., 2009) or there has been replacement. The first hypothesis is reasonable because the simple morphology (slightly to moderately curved, unbranched, unsegmented) can describe many different bacteria from a wide variety of settings. However, it is rejected because this study focused on a very narrow microfacies: the laminated portion of columnar and pseudocolumnar stromatolites from two correlative beds that share similar sediment and sedimentary structures. Therefore, the likelihood of two vastly different localized microbial ecosystems producing the same structures is not high.

Furthermore, several papers have shown strong evidence of fossilized $\mathrm{Fe}(\mathrm{II})$-oxidizing bacteria from hydrothermal vent settings and these are very different from the Gunflintia examples described in this manuscript. Little et al. (2004) compared modern microbes to fossilized examples from ancient hydrothermal iron oxide deposits. They found distinctive morphologies, such as hollow sheaths, twisted ribbons, and branching and dendritic filaments - the latter three forms are not characteristic of Gunflintia. They also noted that in fossil deposits, the filaments form up to $40 \%$ of the laminae, which is much higher than recognized in the Gunflint and Biwabik iron formations. Slack et al. (2007) described preserved Fe(II)-oxidizing bacteria from a Paleoproterozoic (1.7 Ga) volcanosedimentary deposit that similarly showed a dense accumulation of highly curved filaments that are not morphologically analogous to Gunflintia. Most recently, Krepski et al. (2013) showed a variety of fossilized $\mathrm{Fe}(\mathrm{II})$ oxidizing bacteria throughout the Phanerozoic and suggested that there are some key morphological indicators. Specifically, the authors compared fossilized Fe(II)-oxidizing bacteria to hematite-encrusted cyanobacteria for distinguishing the two populations in the rock record. They noted that cyanobacteria contain a wider variety of sheath widths, while $\mathrm{Fe}(\mathrm{II})$ oxidizers are recognized by helical growth, branching, and very random directionality within a dense accumulation of filaments. While this first point allows for Gunflintia to be analogous to Leptothrix, the latter features are not shared with the Gunflint microbiota. Fru et al. (2013) presented a similar study on an early Quaternary marine hydrothermal vent field and demonstrated that in the silica- and iron-rich deposits preserved bacterial molds displayed features distinctly different from Gunflintia in the common occurrence of spherical cells adhered to stalks, branching, and exospores-like features. Moreover, studies of modern $\mathrm{Fe}(\mathrm{II})$-oxidizing bacteria 
show that the iron oxyhydroxides are concentrated as waste product on the outside of the stalks and sheaths, not as cells, so the stalks are carbon poor (Chan et al., 2011).

The Taphonomy hypothesis is better supported by the consistency of facies (shallow-water, centrimetric to decimetric stromatolites of similar microstructure used in this study, associated with ooids and syneresis-cracked, rounded mud rip-ups) and the relationship of preservation to metamorphic gradient. The observations presented in this paper, coupled with Raman studies (Kudryavtsev et al., 2001; Schopf et al., 2002; Bower et al., 2010), show that the least altered units preserve the microfossils as carbon. Areas less protected from the regional prehnite-pumpellyite metamorphism preserve hematite casings. Hematite also dominates in regions associated with contact diabase sills and dikes. Near the main gabbro body, hematite first increases in size and then becomes reduced to magnetite. In localized areas, the magnetite even shows secondary oxidation back to martite. This pattern is also seen in other iron formations globally that have been subjected to different levels of alteration. Furthermore, even the non-stromatolitic occurrences that are not the focus of this paper show cellular remains preserved as carbonaceous (Knoll \& Barghoorn, 1976; Awramik \& Barghoorn, 1977), hematitic (Cloud \& Morrison, 1980), and siliceous outlines (Edwards et al., 2012). Multiple states of microfossil preservation (carbonaceous, hematitic, magenetitic) are also related to iron content and ore genesis in the Neoproterozoic Wadi Kareim banded iron formation of Egypt (El-Habaak \& Mahmoud, 1994).

Finally, it should be noted that the Gunflint microflora, like other fossils, may occur in other preservational states though rare. In a recent paper, Wacey et al. (2013) describe pyritized Gunflintia and Huroniospora, along with epibionts, from the Schreiber locality. Their observations have an important bearing on the present manuscript as it shows that even the most excellent, 'primary' preservation of Paleoproterozoic microfossils show evidence of secondary replacement.

\section{CONCLUSIONS}

The various filaments described in this study are all assigned to Gunflintia Barghoorn (Barghoorn \& Tyler, 1965). The similarity in stromatolite microstructure and lithofacies between collection sites permits the interpretation that all stromatolites studied formed under broadly similar conditions. Therefore, taphonomic variability is a function of post-depositional alteration and not in situ localized microbial ecosystems. Unaltered microfossils were preserved as carbonaceous remains that outlined the original micro-organism, either by early silicification, calci- fication or simply due to the recalcitrant nature of the organic materials. Hematite-bearing microfossils formed when $\mathrm{Fe}(\mathrm{II})$ was brought to the still porous stromatolites via groundwater. The timing and mechanisms for this are unclear, but it could have involved the cellular surfaces of the primary stromatolite builders either adsorbing $\mathrm{Fe}(\mathrm{II})$ or nucleating authigenic, ferrous mineral phases, such as siderite. Low-grade alteration by tectonically driven and younger $\mathrm{O}_{2}$-bearing fluids - perhaps tens to hundreds of millions of years later - then led to the subsequent oxidation of the ferrous iron to ferrihydrite, which ultimately transformed into hematite. Alternatively, ferric oxyhydroxides formed directly at the interface where $\mathrm{Fe}(\mathrm{II})$-bearing groundwater came into contact with shallow oxic fluids. In either case, the regional to localized variations in iron content within the stromatolites argues against iron being sourced from bulk seawater. At higher metamorphic pressures and temperatures within the gabbro contact aureole, the crystal size of the hematite coatings increased and, in some cases, reduced to magnetite (and locally re-oxidized to martite). Therefore, the presence of hematite-coated microfossils is a reflection of taphonomic processes in which the remains of the primary stromatolite builders interacted with $\mathrm{Fe}(\mathrm{II})$-rich groundwater; they do not reflect an original $\mathrm{Fe}(\mathrm{II})$-oxidizing microbial ecosystem. However, it is important to point out that these findings do not negate nor support the hypothesis that Paleoproterozoic oceans were teeming with $\mathrm{Fe}(\mathrm{II})$-oxidizing bacteria, particularly below a chemocline that separated oxygenic cyanobacteria from underlying anoxic and ferruginous waters. The shallow-water ecosystems described in this paper are not associated with banded or 'primary' iron formation, leaving open the possibility that anoxygenic $\mathrm{Fe}(\mathrm{II})$-oxidizing bacteria are yet primarily responsible for sourcing the ferric iron in the bulk of iron formations.

\section{ACKNOWLEDGMENTS}

The authors wish to thank Frank Corsetti for the invitation to present this research at the 2012 Astrobiology Science Conference and the conference participants for helpful feedback. Mark Severson located critical cores and Jeff Bird (Northshore Mining) and Mike Totenhagen (ArcelorMittal Minorca) provided access to important mine outcrops. Other mine samples from ClevelandCliffs properties were collected when the author was consulting for Cliffs-Stone. Phil Fralick was the author's field guide in Thunder Bay and has been a valuable colleague for many years. Todd Greene, William Miller III, Noah Planavsky, and two anonymous reviewers commented on earlier drafts of the manuscript. Support for RSS comes from the National Science Foundation EAR-1251422. Support for KK comes from the Natural 
Sciences and Engineering Research Council of Canada (NSERC).

\section{REFERENCES}

Altermann W, Schopf JW (1995) Microfosils from the Neoarchean Campbell Group, Griqualand West Sequence of the Transvaal Supergroup, and their paleoenvironmental and evolutionary implications. Precambrian Research 75, 65-90.

Amard B, Bertrand-Sarfati J (1997) Microfossils in the $2000 \mathrm{Ma}$ old cherty stromatolites of the Franceville Group, Gabon. Precambrian Research 81, 197-221.

Awramik SM, Barghoorn ES (1977) The Gunflint microbiota. Precambrian Research 5, 121-142.

Awramik SM, Semikhatov MA (1979) The relationship between morphology, microstructure and microbiota in three vertically intergrading stromatolites from the Gunflint Iron Formation. Canadian Journal of Earth Sciences 16, 484-495.

Barghoorn ES, Tyler SA (1965) Microorganisms from the Gunflint Chert. Science 147, 563-577.

Bekker A, Slack JF, Planavsky N, Krapež B, Hofmann A, Konhauser KO, Rouxel OJ (2010) Iron formation: the sedimentary product of a complex interplay among mantle, tectonic, oceanic, and biospheric processes. Economic Geology 105, 467-508.

Bower DM, Steele A, Kater L (2010) Micro Raman spectroscopic investigations of the nature and provenance of mineral and carbonaceous material in the 1.9 Gunflint Formation; redefining $\mathrm{D}$ and $\mathrm{G}$ carbon parameters for the detection of biosignatures. Lunar and Planetary Science Conference XLI, Abstracts 41, $2657 \mathrm{pp}$

Buick R (1990) Microfossil recognition in Archean rock: an appraisal of spheroids and filaments from a 3500 m.y. old chertbarite unit at North Pole, Western Australia. Palaios 5, 441459.

Cady SL, Farmer JD, Grotzinger JP, Schopf JW, Steele A (2003) Morphological biosignature and the search for life on Mars. Astrobiology 3, 351-368.

Chan CS, Fakra SC, Emerson D, Fleming EJ, Edwards KJ (2011) Lithotropic iron-oxidizing bacteria produce organic stalk to control mineral growth: implications for biosignature formation. The ISME Journal 5, 717-727.

Clarke WA, Konhauser KO, Thomas JC, Bottrell SH (1997) Ferric hydroxide and ferric hydroxysulfate precipitation by bacteria in an acid mine drainage lagoon. FEMS Microbiology Reviews 20, 351-361.

Cloud P (1965) The significance of the Gunflint (Precambrian) microflora. Science 148, 27-35.

Cloud PE Jr, Licari GR (1968) Microbiotas of the banded iron formations. Proceedings of the National Academy of Sciences 61, 779-786.

Cloud PE Jr, Semikhatov MA (1969) Proterozoic stromatolite zonation. American Journal of Science 267, 1017-1061.

Cloud P, Morrison K (1980) New microbial fossils from 2 Gyr old rocks in northern Michigan. Geomicrobiology Journal 2, 161-178.

Dabous AA (2002) Uranium isotopic evidence for the origin of the Bahariya iron deposits, Egypt. Ore Geology Reviews 19, 165-186.

Dupraz C, Reid RP, Braissant O, Decho AW, Norman RS, Visscher PT (2009) Processes of carbonate precipitation in modern microbial mats. Earth-Science Reviews 96, 141-162.

Edwards CT, Pufahl PK, Hiatt EE, Kyser TK (2012) Paleoenvironmental and taphonomic controls on the occurrence of Paleoproterozoic microbial communities in the $1.88 \mathrm{Ga}$
Ferriman Group, Labrador Trough, Canada. Precambrian Research 212-213, 91-106.

El-Habaak GH, Mahmoud MS (1994) Carbonaceous bodies of debatable organic provenance in the Banded Iron Formation of the Wadi Kareim area, Eastern Desert, Egypt. Journal of African Earth Sciences 19, 125-133.

Emerson D (2000) Microbial oxidation of $\mathrm{Fe}(\mathrm{II})$ and $\mathrm{Mn}$ (II) at circumneutral pH. In Environmental Microbe-Metal Interactions (ed. Lovley DR). ASM Press, Washington, DC, pp. 31-51.

Emerson D, Moyer CL (2002) Neutrophilic Fe-oxidizing bacteria are abundant at the Loihi Seamount hydrothermal vents and play a major role in $\mathrm{Fe}$ oxide deposition. Applied and Environmental Microbiology 68, 3085-3093.

Emerson D, Revsbech NP (1994a) Investigation of an ironoxidizing microbial mat community located near Aarhus, Denmark. Field studies. Applied and Environmental Microbiology 60, 4022-4031.

Emerson D, Revsbech NP (1994b) Investigation of an ironoxidizing microbial mat community located near Aarhus, Denmark: laboratory studies. Applied and Environmental Microbiology 60, 4032-4038.

Emerson D, Rentz JA, Lilburn TG, Davis RE, Aldrich H, Chan CS, Moyer CL (2007) A novel lineage of Proteobacteria involved in formation of marine $\mathrm{Fe}$-oxidizing microbial mat communities. PLoS ONE 2, e667.

Evans KA, McCuaig TC, Leach D, Angerer T, Hagemann SG (2013) Banded iron formation to iron ore: a record of the evolution of Earth environments? Geology 41, 99-102.

Fairchild IJ, Knoll AH, Swett K (1991) Coastal lithofacies and biofacies associated with syndepositional dolomitization and silicification (Draken Formation, Upper Riphean, Svalbard). Precambrian Research 53, 165-197.

Ferris FG, Fyfe WS, Beveridge TJ (1988) Metallic ion binding by Bacillus subtilis: implications for the fossilization of microorganisms. Geology 16, 149-152.

Fischer WW, Knoll AH (2009) An iron shuttle for deepwater silica in late Archean and early Paleoproterozoic iron formation. Geological Society of America Bulletin 121, 222-235.

Fleming EJ, Davis R, McAllister S, Chan CS, Moyer CL, Tebo B, Emerson D (2013) Hidden in plain sight: discovery of sheath forming, Fe-oxidizing Zetaproteobacteria at Loihi Seamount. FEMS Microbial Ecology 85, 116-127.

Forget NL, Murdock SA, Juniper SK (2010) Bacterial diversity in Fe-rich hydrothermal sediments at two South Tonga Arc submarine volcanoes. Geobiology 8, 417-432.

Fralick PW (1988) Microbial bioherms, lower Proterozoic Gunflint Formation, Thunder Bay, Ontario. In Reefs; Canada and Adjacent Areas (eds Geldsetzer HHJ, James NP, Tebbutt GE). Memoir - Canadian Society of Petroleum Geologists 13, 24-29.

French BM (1973) Mineral assemblages in diagenetic and low grade metamorphic iron-formation. Economic Geology 68, 1063-1074.

Frost CD, von Blanckenburg F, Schoenberg R, Frost BR, Swapp SM (2007) Preservation of Fe isotope heterogeneities during diagenesis and metamorphism of banded iron formation. Contributions to Mineralogy and Petrology 153, 211-235.

Fru EC, Ivarsson M, Kilias SP, Bengtson S, Belivanova V, Marone F, Fortin D, Broman C, Stampanoni M (2013) Fossilized iron bacteria reveal a pathway to the biological origin of banded iron formation. Nature Communications 4. doi:10.1038/ncomms 3050 .

Ghiorse WC, Ehrlich HL (1992) Microbial biomineralization of iron and manganese. In Biomineralization Processes (eds Skinner 
HCW, Fitzpatrick RW). Catena Supplement, Cremlingen, Germany, pp. 75-99.

Gruner JW (1922) Organic matter and the origin of the Biwabik iron-bearing formation of the Mesabi range. Economic Geology and the Bulletin of the Society of Economic Geologists 17, 407-460.

Hallbeck L, Pederson K (1990) Culture parameters regulating stalk formation and growth rates of Gallionella ferruginea. Journal of General Microbiology 136, 1675-1680.

Harder EC (1919) Iron-depositing bacteria and their geologic relations. U. S. Geological Survey Professional Paper 113, 89.

Hemming SR, Hanson GN, McLennan SM (1995a) Precambrian crustal blocks in Minnesota; neodymium isotope evidence from basement and metasedimentary rocks. In Contributions to Precambrian Geology of Lake Superior Region (eds Sims PK, Carter LMH). US Geological Survey Bulletin 1995, U1-U15.

Hemming SR, McLennan SM, Hanson GN (1995b) Geochemical and $\mathrm{Nd} / \mathrm{Pb}$ isotopic evidence for the provenance of the early Proterozoic Virginia Formation, Minnesota; implications for the tectonic setting of the Animikie Basin. Journal of Geology 103, 147-168.

Hesse R (1989) Silica diagenesis: origin of inorganic and replacement cherts. Earth-Science Reviews 26, 253-284.

Hoffman PF (1987) Early Proterozoic foredeeps, foredeep magmatism, and Superior-type iron-formations of the Canadian Shield. In Proterozoic Lithospheric Evolution (ed. Kröner A). American Geophysical Union, Washington, DC, Geodynamics Series 17 , pp. 85-98.

Hofmann H (1969) Stromatolites from the Proterozoic Animikie and Sibley groups. Geological Survey of Canada Paper, 68, $77 \mathrm{pp}$.

Holland HD (1973) The oceans: a possible source of iron in ironformations. Economic Geology 68, 1169-1172.

Hollings P, Smyk MC, Heaman LM, Halls H (2010) The geochemistry, geochronology and paleomagnetism of dikes and sills associated with the Mesoproterozoic Midcontinent Rift near Thunder Bay, Ontario, Canada. Precambrian Research 183, $553-571$.

Holm NG (1989) The ${ }^{13} \mathrm{C} /{ }^{12} \mathrm{C}$ ratios of siderite and organic matter of a modern metalliferous hydrothermal sediment and their implications for banded iron formations. Chemical Geology $77,41-45$.

Hyslop EV, Valley JW, Johnson CM, Beard BL (2008) The effects of metamorphism on $\mathrm{O}$ and $\mathrm{Fe}$ isotope compositions in the Biwabik Iron Formation, northern Minnesota. Contributions to Mineralogy and Petrology 55, 313-328.

Igisu M, Uenod Y, Shimojimae M, Nakashimab S, Awramik SM, Ohtae H, Maruyamaa S (2009) Micro-FTIR spectroscopic signatures of Bacterial lipids in Proterozoic microfossils. Precambrian Research 173, 19-26.

Isley AE (1995) Hydrothermal plumes and the delivery of iron to banded iron formation. Journal of Geology 103, 169-185.

Jørgensen BB (1982) Mineralization of organic matter in the seabed - the role of sulfate reduction. Nature 296, 643-645.

Juying L (1996) Microbial fossil-types and characteristics of Xuanlong hematite deposit. In Aspects of Biomineralization (ed. Lianjun Y). Seismological Press, Beijing, China, pp. 105-113.

Kappler A, Pasquero C, Konhauser KO, Newman DK (2005) Deposition of banded iron formations by anoxygenic phototrophic $\mathrm{Fe}(\mathrm{II})$-oxidizing bacteria. Geology 33, 865-868.

Köhler I, Konhauser KO, Papineau D, Bekker A, Kappler A (2013) Biological carbon precursor to diagentic siderite with spherical structures in iron formations. Nature Communications 4, 1741. doi: $10.1038 /$ ncomms 2770 .
Knauth LP (1979) A model for the origin of chert in limestone. Geology 7, 274-277.

Knoll AH (1985) Exceptional preservation of photosynthetic organisms in silicified carbonates and silicified peats. Philosophical Transcations of the Royal Society of London B 311, 111-122.

Knoll AH (2003) Life on a Young Planet: the First Three Billion Years of Evolution on Earth. Princeton University Press, New Jersey.

Knoll A, Barghoorn ES (1976) A Gunflint-type microbiota from the Duck Creek Dolomite, Western Australia. Origins of Life 7, 417-423.

Knoll AH, Simonson B (1981) Early Proterozoic microfossils and penecontemporaneous quartz cementation in the Sokoman Iron Formation, Canada. Science, New Series 211, 478-480.

Konhauser KO, Fisher QJ, Fyfe WS, Longstaffe FJ, Powell MA (1998) Authigenic mineralization and detrital clay binding by freshwater biofilms: the Brahmani River, India. Geomicrobiology Journal 15, 209-222.

Konhauser KO, Hamade T, Raiswell R, Morris RC, Ferris FG, Southam G, Canfield DE (2002) Could bacteria have formed the Precambrian banded iron formations? Geology 30, 1079-1082.

Konhauser KO, Jones B, Phoenix VR, Ferris G, Renaut RW (2004) The microbial role in hot spring silicification. Ambio 33, $552-558$.

Konhauser KO, Newman DK, Kappler A (2005) The potential significance of microbial $\mathrm{Fe}(\mathrm{III})$ reduction during deposition of Precambrian banded iron formations. Geobiology 3, 167-177.

Krepski ST, Hanson TE, Chan CS (2012) Isolation and characterization of a novel biomineral stalk-forming ironoxidizing bacterium from a circumneutral groundwater seep. Environmental Microbiology 14, 1671-1680.

Krepski ST, Emerson D, Hredzak-Showalter PL, Juther GW III, Chan CS (2013) Morphology of biogenic iron oxides records microbial physiology and environmental conditions: toward interpreting iron microfossils. Geobiology 11, 457-471.

Kudryavtsev AB, Schopf JW, Agresti DG, Wdowiak TJ (2001) In situ laser-Raman imagery of Precambrian microscopic fossils. Proceedings of the National Academy of Sciences 98, 823-826.

Lager I (2001) The geology of the Palaeoproterozoic limestonehosted Dannemora iron deposit, Sweden. Rapporter och Meddelanden-Sveriges Geologiska Undersokning 107, 49.

Li YL, Konhauser KO, Cole DR, Phelps TJ (2011) Mineral ecophysiological evidence for microbial activity in banded iron formation. Geology 39, 707-710.

Li YL, Konhauser KO, Kappler A, Hao X-L (2013) Experimental low-grade alteration of biogenic magnetite indicates microbial involvement in generation of banded iron formations. Earth and Planetary Science Letters 361, 229-237.

Little CTS, Glynn SEJ, Mills RA (2004) Four-hundred-andninety-million-year record of bacteriogenic iron oxide precipitation at sea-floor hydrothermal vents. Geomicrobiology Journal 21, 415-429.

Markun CD, Randazzo AF (1980) Sedimentary structures in the Gunflint Iron Formation, Schreiber Beach, Ontario.

Precambrian Research 12, 287-310.

McBeth JM, Little BJ, Ray RI, Farrar KM, Emerson D (2011) Neutrophilic iron-oxidizing 'Zetaproteobacteria' and mild steel corrosion in nearshore marine environments. Applied and Environmental Microbiology 77, 1405-1412.

Miller JD Jr, Severson MJ (2002) Geology of the Duluth Complex. In Geology and Mineral Potential of the Duluth Complex and Related Rocks of Northeastern Minnesota (eds Miller JD Jr, Green JC, Severson MJ, Chandler VW, Hauck SA, 
Peterson DM, Wahl TE). Minnesota Geological Survey Report of Investigations 58, pp. 106-143.

Moore ES (1918) The iron formation on Belcher Islands, Hudson Bay, with special reference to its origin and its associated algal limestones. Journal of Geology 1918, 412-438.

Nealson KH (1982) Microbiological oxidation and reduction of iron. In Mineral Deposits and the Evolution of the Biosphere (eds Holland HD, Schidlowski M). Springer-Verlag, New York, pp. 51-66.

Nudds JR, Selden PA (2008) Fossil Ecosystems of North America: A Guide to the Sites and Their Extraordinary Biotas. University of Chicago Press, Chicago, IL, 288 pp.

Oehler JH (1976) Experimental studies in Precambrian paleontology: structural and chemical changes in blue-green algae during simulated fossilization in synthetic chert. Geological Society of America Bulletin 87, 117-129.

Ojakangas RW, Severson MJ, Jongewaard PK (2011) Geology and sedimentology of the Paleoproterozoic Animikie Group; the Pokegama Formation, the Biwabik Iron Formation, and Virginia Formation of the eastern Mesabi Iron Range and Thomson Formation near Duluth, northeastern Minnesota. In Archean to Anthropocene; Field Guides to the Geology of the Mid-Continent of North America (eds Miller JD, Hudak GJ, Wittkop C, McLaughlin PI). Geological Society of America Field Guide 24, pp. 101-120.

Orange F, Lalonde SV, Konhauser KO (2013) The formation and preservation of Synechococcus elongates cell moulds in simulated silica sinter: implications for the identification of microfossils. Geomicrobiology Journal 30, 327-336.

Phoenix VR, Adams DG, Konhauser KO (2000) Cyanobacterial viability during hydrothermal biomineralisation. Chemical Geology 169, 329-338.

Planavsky N, Rouxel O, Bekker A, Shapiro R, Fralick P, Knudsen A (2009) Iron-oxidizing microbial ecosystems thrived in the late Paleoproterozoic redox stratified oceans. Earth and Planetary Science Letters 286, 230-242.

Posth NR, Konhauser KO, Kappler A (2013) Microbiological processes in banded iron formation deposition. Sedimentology 60, 1733-1754.

Poulton SW, Fralick PW, Canfield DE (2004) The transition to a sulphidic ocean $\sim 1.84$ billion years ago. Nature 431, 173-177.

Pufahl PK, Fralick PW (2004) Depositional controls on Palaeoproterozoic iron formation accumulation, Gogebic Range, Lake Superior region, USA. Sedimentology 51, 791-808.

Rasmussen B, Krapez B, Meier DB (2014) Replacement origin for hematite in $2.5 \mathrm{Ga}$ banded iron formation: evidence for post depositional oxidation of iron-bearing minerals. Geological Society of America Bulletin 126, 438-446.

Saini G, Chan CS (2013) Near-neutral surface charge and hydrophilicity prevent mineral encrustation of Fe-oxidizing micro-organisms. Geobiology 11, 191-200.

Salama W, El Aref MM, Gaupp R (2013) Mineral evolution and processes of ferruginous microbialite accretion-an example from the Middle Eocene stromatolitic and ooidal ironstones of the Bahariya Depression, Western Desert, Egypt. Geobiology 11, $15-28$.

Schelble RT, Westall F, Allen CC (2004) 1.8 Ga iron-mineralized microbiota from the Gunflint Iron Formation, Ontario, Canada: implications for Mars. Advances in Space Research 33, 1268 1273.

Schopf JW, Kudryavtsev AB, Agresti DG, Wdowiak TJ, Czaja AD (2002) Laser-Raman imagery of Earth's earliest fossils. Nature 416, 73-76.
Schulz KJ, Cannon WF (2007) The Penokean orogeny in the Lake Superior region. Precambrian Research 157, 4-25.

Sergeev VN (2009) The distribution of microfossil assemblages in Proterozoic rocks. Precambrian Research 173, 212-222.

Severson MJ, Heine JJ, Patelke MM (2009) Geologic and stratigraphic controls of the Biwabik Iron Formation and the aggregate potential of the Mesabi Iron Range, Minnesota.

University of Minnesota Duluth, Natural Resources Research Institute, Technical Report NRRI/TR-2009/09.

Shapiro RS (2009) Alteration of stromatolite biosignatures in the Biwabik Iron-Formation; relevance to astrobiology. Institute on Lake Superior Geology 55th Annual Meeting Proceedings 55, 7071.

Simonson BM (2011) Iron ore deposits associated with Precambrian iron formations. Episodes 7, 119-120.

Slack JF, Grenne T, Bekker A, Rouxel OJ, Lindberg PA (2007) Suboxic deep seawater in the late Paleoproterozoic: evidence from hematitic chert and iron formation related to seafloorhydrothermal sulfide deposits, central Arizona, USA. Earth and Planetary Science Letters 255, 243-256.

Søgaard EG, Medenwaldt R, Abraham-Peskir JV (2000) Conditions and rates of biotic and abiotic iron precipitation in selected Danish freshwater plants and microscopic analysis of precipitate morphology. Water Research 34, 2675-2682.

Strother PK, Tobin K (1987) Observations on the Genus Huroniospora Barghoorn: implications for paleoecology of the Gunflint microbiota. Precambrian Research 36, 323-333.

Tazaki K (1993) Processes of formation of bacterial iron and carbon minerals. Science Reports of the Kanazawa University 38, 59-77.

Tobin KJ (1990) The paleoecology and significance of the Gunflint-type microbial assemblages from the Frere Formation (Early Proterozoic), Nabberu Basin, Western Australia. Precambrian Research 47, 71-81.

van Veen WL, Mulder EG, Deinema MH (1978) The Sphaerotilus-Leptothrix group of bacteria. Microbiology Reviews 42, 329-356.

Wacey D, McLoughlin N, Kilburn MR, Suanders M, Cliff JB, Kong C, Barley ME, Brasier MD (2013) Nanoscale analysis of pyritized microfossils reveals differential heterotrophic consumption in the $\sim 1.9-\mathrm{Ga}$ Gunflint chert. Proceedings of the National Academy of Sciences 110, 8020-8024.

Walter MR, Goode ADT, Hall WDM (1976) Microfossils from a newly discovered Precambrian stromatolitic iron formation in Western Australia. Nature 261, 221-223.

Widdel F, Schnell S, Heising S, Ehrenreich A, Assmus B, Schink B (1993) Ferrous iron oxidation by anoxygenic phototrophic bacteria. Nature 362, 834-836.

Wilson JP, Woodward WF, Johnston DT, Knoll AH, Grotzinger JP, Walter MR, McNaughton NJ, Simon M, Abelson J, Schrag DP, Summons R, Allwood A, Andres M, Gammon C, Garvin J, Rashby S, Schweizer M, Watters WA (2010) Geobiology of the late Paleoproterozoic Duck Creek Formation, Western Australia. Precambrian Research 179, 135-149.

Yee N, Phoenix VR, Konhauser KO, Benning LG, Ferris FG (2003) The effect of cyanobacteria on silica precipitation at neutral $\mathrm{pH}$ : implications for bacterial silicification in geothermal hot springs. Chemical Geology 199, 83-90.

Yongding D, Haiming S, Jiying S (2004) Fossil bacteria in Xuanlong iron ore deposits of Hebei Province. Science in China (Earth Sciences) 47, 347-356.

Yun Z (1984) A Gunflint type of microfossil assemblage from early Proterozoic stromatolitic cherts in China. Nature 309, 547-549. 